\title{
Considerações sobre o discurso fotográfico em Cabeça do Cachorro, de Araquém Alcântara
}

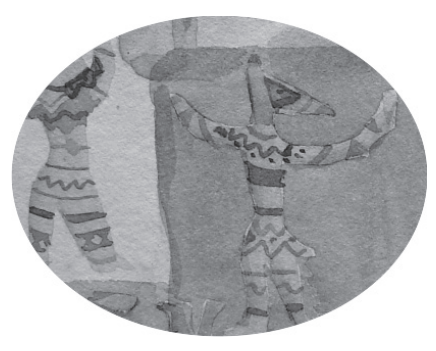

Karliane Macedo Nunes ${ }^{8}$

\section{Resumo}

Este artigo buscou realizar uma breve demonstração dos aspectos imagéticos envolvidos na construção do livro de fotografias Cabeça do Cachorro (2008), de Araquém Alcântara, com o objetivo de observar como essas representações contemporâneas, com uma linguagem própria, podem reforçar ou enfraquecer discursos hegemônicos produzidos sobre as identidades indígenas até então.

Palavras-chave: Fotografia. Representações identitárias. Análise.

\begin{abstract}
This article intends to realize a brief demonstration of the imagetic aspects involved in the construction of the photography's book Cabeça do Cachorro (2008), from Araquém Alcântara. The objective is to observe as these contemporaries representations, with a proper language, can strengthen or weaken produced hegemonic speeches about the indigenous identities until then.
\end{abstract}

Keywords: Photography. Identity representations. Analysis.

8 Jornalista e mestre pelo Programa Multidisciplinar de Pós-graduação em Cultura e Sociedade da Universidade Federal da Bahia. Professora assistente do Curso de Comunicação Social da Universidade Federal do Amazonas, campus de Parintins. Email: karliane77@yahoo.com.br / (92) 91489106. 
Desde os primeiros contatos dos povos europeus com os moradores do chamado Novo Mundo, há mais de 500 anos, que representações acerca das diferentes etnias indígenas são criadas e recriadas historicamente, servindo como veículos de produção de sentido e construção das identidades desses povos. Tanto nas primeiras representações, datadas do século XVI, até os dias atuais, descrições sugeridas a partir do pensamento ocidental continuam a dar ênfase a discursos em torno da dicotomia entre civilização e barbárie, que alimentam a tradução do espanto, o encantamento com o estado da natureza, visões de um paraiso perdido, dúvidas sobre a existência da alma, fantasias sobre canibalismo e a ferocidade dos habitantes da nova terra (FREIRE, 2005).

A partir do século XVI, os viajantes europeus empenharam-se em construir narrativas nas quais o homem branco emergia como hierarquicamente superior em relação aos povos indígenas, comumente descritos como selvagens, preguiçosos, inferiores, incapazes e incivilizados, e, ao mesmo tempo, dignos, ingênuos e puros. Nesse sentido, a carta de Pero Vaz de Caminha se configura como um registro exemplar do relato do encontro entre os "povos civilizados do Ocidente" e os "índios", habitantes do Novo Mundo.

Também no século XIX essa visão persiste no Brasil, uma vez que ainda se acreditava na superioridade das raças puras, sobretudo a branca, em oposição à degenerescência das misturas. De acordo com Freire (2005), no rastro dessa lógica é que se produziram e multiplicaram-se - na mídia, na literatura e nas artes - discursos e imagens tão equivocadas quanto difundidas como autênticas acerca das etnias indígenas. Ela afirma:

A forma negativa do colonizador de apontar índios como diferentes pode ser em parte decorrente das dificuldades dos primeiros viajantes europeus em compreenderem a vida social desses sujeitos, atribuindo-lhes um estatuto de alteridade exótica, mas por outro lado, decorrente da legitimação da conquista e espoliação dos indígenas. Essa forma negativa de representá-los pode ser observada ainda hoje, em alguns produtos culturais, como é o caso dos jornais em circulação no País, justamente por causa da fixidez que é típica dos estereótipos (FREIRE, 2005).

A autora reforça ainda que a atribuição de características faz parte de um processo arbitrário e desigual de forças, em um jogo no qual as formas 
pelas quais cada povo se autodenomina não faz sentido para o colonizador, que sempre preferiu generalizar características superficiais em detrimento das individualidades (FREIRE, 2005).

Nesse sentido, Durval Albuquerque traz uma contribuição importante quando afirma que as identidades culturais são sempre fabricações sociais e históricas e sugere o seguinte questionamento: [...] Por que não pensarmos em construção de singularidades culturais ao invés de identidades culturais?. E vai mais além: [...] O singular só existe na relação com aquilo do qual se singulariza, a singularidade é relacional, situacional e provisória. Para se afirmar singular é preciso ao mesmo tempo afirmar também aquilo em relação a que se singulariza (ALBUQUERQUE, 2007, p. 21). Ainda para o autor, a identidade, pelo contrário, pretensamente se constrói a partir de um fechamento para o diferente, para aquilo que está fora se sua própria lógica.

A esse fechar-se para o diferente é que Freire se refere quando diz que os colonizadores nunca se preocuparam com as imagens construídas pelos próprios colonizados acerca de si mesmos. Ora, as múltiplas identidades indígenas, em diferentes momentos da História, são construídas através de valores e contextos diferenciados.

E é assim que se torna possível afirmar que a ideia de uma identidade total e homogênea em relação aos diferentes grupos indígenas não tem como se sustentar. As identidades são construídas dentro e não fora do discurso, as identidades referem-se à utilização dos recursos da História, da linguagem e da cultura para a produção não daquilo que nós somos, mas daquilo no qual nos tornamos (FREIRE, 2005).

Stuart Hall também argumenta a favor do conceito da identidade enquanto uma construção, um processo. Ao examinar as formas como a diferença é marcada através das diversas mídias, inclusive na fotografia, o autor afirma que desde o século XIX aspectos diferenciados atribuídos à raça e à etnia são utilizados para marcar a diferença de forma essencialista e dicotômica, por meio da construção de estereótipos. Para ele, são as práticas de significação que estruturam o nosso olhar para as coisas. E nesse sentido, afirma: Reduzir as culturas de negros e indios à natureza consiste em naturalizar a diferença, consiste em uma estratégia representacional destinada a fixar a "diferença" e assim garanti-la para sempre (HALL, 1997).

Assim, é possível afirmar que as identidades indígenas relacionam-se de forma mais contundente com as maneiras que as suas representações vêm 
sendo construídas a partir do lugar do "outro", não podendo assim coincidir nem serem idênticas aos processos dos sujeitos que nelas são investidos.

As comemorações realizadas no ano de 2000 em torno dos 500 anos do "descobrimento" do Brasil foram emblemáticas no sentido de dar visibilidade a contradiscursos protagonizados pelos indígenas e que tiveram grande repercussão na mídia nacional. Se, por um lado, houve por parte dos discursos oficiais de Estado uma repetição da visão construída para os índios ao longo da História (como o reforço das características de coragem, ingenuidade e portadores de uma natureza primitiva); por outro lado, foi o momento do conflito ser instaurado e ganhar eco a partir de tensões provocadas por diversas ações de resistência política por parte de diferentes etnias indígenas. ${ }^{1}$

Desse modo, emergiu o conflito entre as representações identitárias indígenas, através do confronto entre os discursos oficiais, ocidentais e hegemônicos e o dos próprios indígenas, que buscaram uma outra forma de posicionamento.

É nesse sentido que a observação e a análise crítica das diferentes formas de representação indígenas que são construídas na atualidade continuam a ser importantes para a reflexão acerca das práticas de significação identitárias e de como esses discursos refletem no entendimento e no imaginário sobre as etnias indígenas.

\section{Fotografia e construção de sentido}

Parte integrante do cotidiano de grande parte do homem contemporâneo, as imagens fotográficas introduziram a maneira muito particular de produzir, armazenar, perceber e interpretar informações. Vilém Flusser afirma no seu Filosofia da Caixa Preta (2002) que houve duas revoluções fundamentais na estrutura cultural: a primeira, a invenção da escrita linear, que inaugurou a História; a segunda, a invenção das imagens técnicas, que teria inaugurado um modo de ser dificilmente definível. Para ele, a aparente objetividade da imagem técnica é ilusória, porque são tão simbólicas quanto o são todas as imagens (FLUSSER, 2002, p. 14).

De fato, a complexidade que envolve todo o processo fotográfico vai desde escolhas materiais (equipamento, tipo de filme) até os aspectos de ordem 
mais subjetiva (como a escolha do tema fotografado). Isso tudo reflete também na forma como as fotografias são apreendidas e significadas.

Reflexões que buscam compreender os possíveis significados que as fotografias criam devem considerar a sua configuração expressiva (composição), além dos contextos em que essas imagens são construídas. É nesse sentido que Barbosa e Cunha afirmam: O contexto é crucial [...] não por ser definitivo, mas por ser provocativo, sugestivo, por viabilizar a construção de um quadro de possibilidades (BARBOSA e CUNHA, 2006, p. 55).

Christian Metz corrobora a ideia de que uma fotografia, a despeito da analogia que a marca, aciona os mais diferentes códigos. Ele explica:

A “imagem” não constitui um império autônomo e cerrado, um mundo fechado sem comunicação com o que o rodeia. As imagens - como as palavras, como todo o resto - não poderiam deixar de ser "consideradas" nos jogos de sentido, nos mil movimentos que vêm regular a significação no seio das sociedades. A partir do momento em que a cultura se apodera do texto icônico - e a cultura já está presente no espírito do criador de imagens -, ele, como todos os outros textos, é oferecido à impressão da figura e do discurso (METZ, 1973, P. 10).

Ao considerar que interpretações acerca de fotografias não podem deixar de ser consideradas nos jogos de sentido, nas muitas possibilidades de significação que fazem parte das sociedades e das culturas, propomos uma análise mais abrangente e comprometida com o diálogo entre as características inerentes à fotografia.

Nessa perspectiva, a semiótica de Charles Sanders Peirce, filósofo norteamericano que desenvolveu uma filosofia científica das linguagens como instrumento que permitisse o diálogo com diversas áreas do conhecimento de modo dinâmico, pode contribuir com a reflexão aqui proposta. De modo mais específico (e também mais simplista, é preciso deixar claro), as categorias peirceanas da experiência que dizem respeito ao signo ${ }^{(2)}$ em relação ao seu objeto (o ícone, o índice e o símbolo) são as que nos interessa por ora.

É importante colocar ainda que o signo em Peirce não se confunde com o objeto. É, ao contrário, uma mediação deste. O signo vai ao observador e 
o observador vai ao signo, munido com as suas experiências de mundo, tanto psicológicas quanto culturais e sociais. Como já foi exposto em artigo anterior: [...] o signo não pode representar o objeto em sua totalidade; ele representa o objeto de alguma forma. Eé dessa maneira que ele deixa um espaço significativo para a mente potencialmente interpretadora daquele que o recebe (NUNES, 2008).

O signo icônico é aquele que apresenta uma relação de similaridade com o seu referente, embora em graus diferenciados (PEIRCE, 1990). Assim, o caráter icônico vincula-se à qualidade (cores e formas, por exemplo) e é percebido pela noção de similaridade. É o único independente da tricotomia peirceana.

Para Peirce, fotografias são de certo modo, exatamente como os objetos que elas representam e, portanto, icônicas. Por outro lado, elas mantêm uma "igação física" com o seu objeto, o que as torna indexicais, pois a imagem fotográfica é obrigada fisicamente a corresponder ponto a ponto à natureza (PEIRCE apud SANTAELLA, 2005, p. 110).

O índice carrega algo de iconicidade e o símbolo, por sua vez, algo de iconicidade e indicialidade. A partir dessas informações, é possível apresentar uma espécie de mapa lógico de possibilidades de interpretação: quando se está diante de um ícone, tende-se a gerar um rema (hipótese); diante de um índice, tende-se a gerar um dicente (uma proposição); e diante de um símbolo, a tendência é gerar um argumento.

O ícone parece ser (não é), o que quer dizer que está aberto para as possibilidades; o índice direto é (gera um dicente), enquanto o argumento refere-se à interpretação argumentativa, que depende do conhecimento de um código.

\section{Cabeça do cachorro}

No final de 2008, o médico Dráuzio Varella e o fotógrafo Araquém Alcântara lançaram um livro de texto e fotografias intitulado Cabeça do Cachorro, ${ }^{3}$ amplamente divulgado na mídia brasileira como uma investigação sobre os mistérios e belezas de uma das regiões mais inóspitas do mundo, o desabitado Noroeste do Estado do Amazonas, na fronteira com a Colômbia e Venezuela (VARELLA e ALCÂNTARA, 2008). O título do livro refere-se à forma pela qual as pessoas que habitam a região 
a chamam, em razão do traçado de suas fronteiras. Já nas primeiras páginas, Varella explica:

\begin{abstract}
Pegue o mapa do Brasil. Olhe para cima e para a esquerda, no extremo Noroeste do Estado do Amazonas. O contorno da fronteira com Venezuela e Colômbia não desenha a cabeça de um cachorro? É a essa região que dedicamos este livro: o Alto Rio Negro, terra das florestas mais preservadas da Amazônia. Sobrevoá-las é viver o êxtase. Até onde a vista alcança, são 360 graus de mata virgem; parece o mar (VARELLA e ALCÂNTARA, 2008).
\end{abstract}

Araquém Alcântara, responsável pelas cem imagens que constituem o livro, é considerado o precursor da fotografia de natureza do Brasil, além de ser um dos grandes representantes do estilo em escala internacional. Em quase 40 anos de carreira, tem 36 livros publicados e gosta de se definir como o "guardador de florestas". A região-tema do livro Cabeça do Cachorro ocupa mais de 200 mil km² de floresta e abriga 700 povoamentos indígenas de 23 diferentes etnias que, de acordo com o arqueólogo da Universidade de São Paulo, Eduardo Neves, vivem no local há mais de três mil anos.

Este artigo concentra-se em apenas algumas fotografias do referido livro, com o foco nas imagens da população indígena que habita a região, não levando em consideração os elementos textuais que dele fazem parte. O objetivo aqui é tecer algumas considerações acerca dessas fotografias a partir dos discursos construídos ao longo da História sobre as culturas e identidades dos povos indígenas, a fim de verificar como o discurso imagético atual produzido pelo fotógrafo sobre determinados povos da região amazônica brasileira pode reforçar ou enfraquecer os discursos hegemônicos de representação dos indígenas produzidos até então.

O fato de esses registros veicularem cenas de um Brasil praticamente inacessível para a maioria dos brasileiros potencializa tanto a importância do trabalho realizado pelo fotógrafo, enquanto mídia criadora de sentidos, quanto a necessidade de um olhar mais atento em relação a essas recentes formas de representação, que vêm sendo divulgadas amplamente, inclusive em âmbito internacional. 


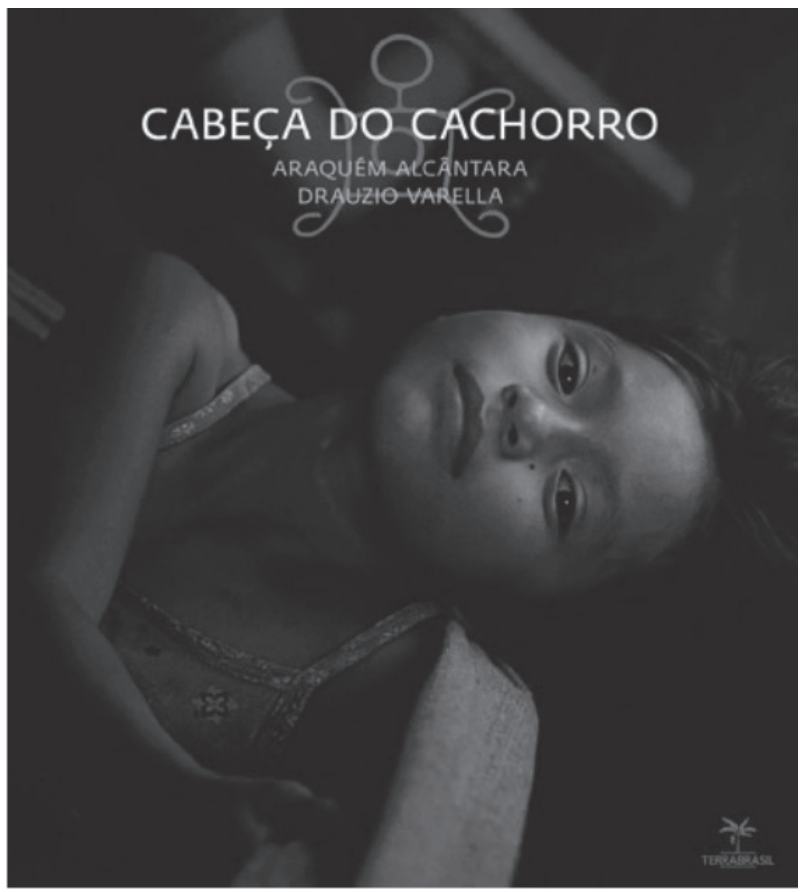

Fotografia 1. Araquém Alcântara.

A capa do livro Cabeça do Cachorro veicula a fotografia de uma menina de etnia baníua, da comunidade Fonte Boa. Deitada em uma rede, a menina encara a câmera e estabelece, dessa forma, uma comunicação direta com o observador da imagem. Esse tipo de olhar, dirigido ao espectador, constituise em um traço enunciativo típico do retrato e indica que o personagem tem consciência de que está sendo fotografado (SOUZA, 2006, p. 117).

Também Cleide Campelo explica que o rosto é um importante canal para a expressão das emoções e que, na cultura ocidental, é a parte do corpo mais permitida de ser mostrada. Ela afirma: Sendo sobre o rosto que as interdições aparentemente atuam menos, no sentido de que é uma área aparentemente para ser exibida, e por isso mesmo o rosto é uma área absolutamente demarcada pela cultura (CAMPELO, 1997, p. 69).

A menina da capa, ao mesmo tempo em que parece intimar, convida o receptor com o olhar, e o fato dessa imagem ter sido veiculada na capa da publicação reforça essa ideia. 


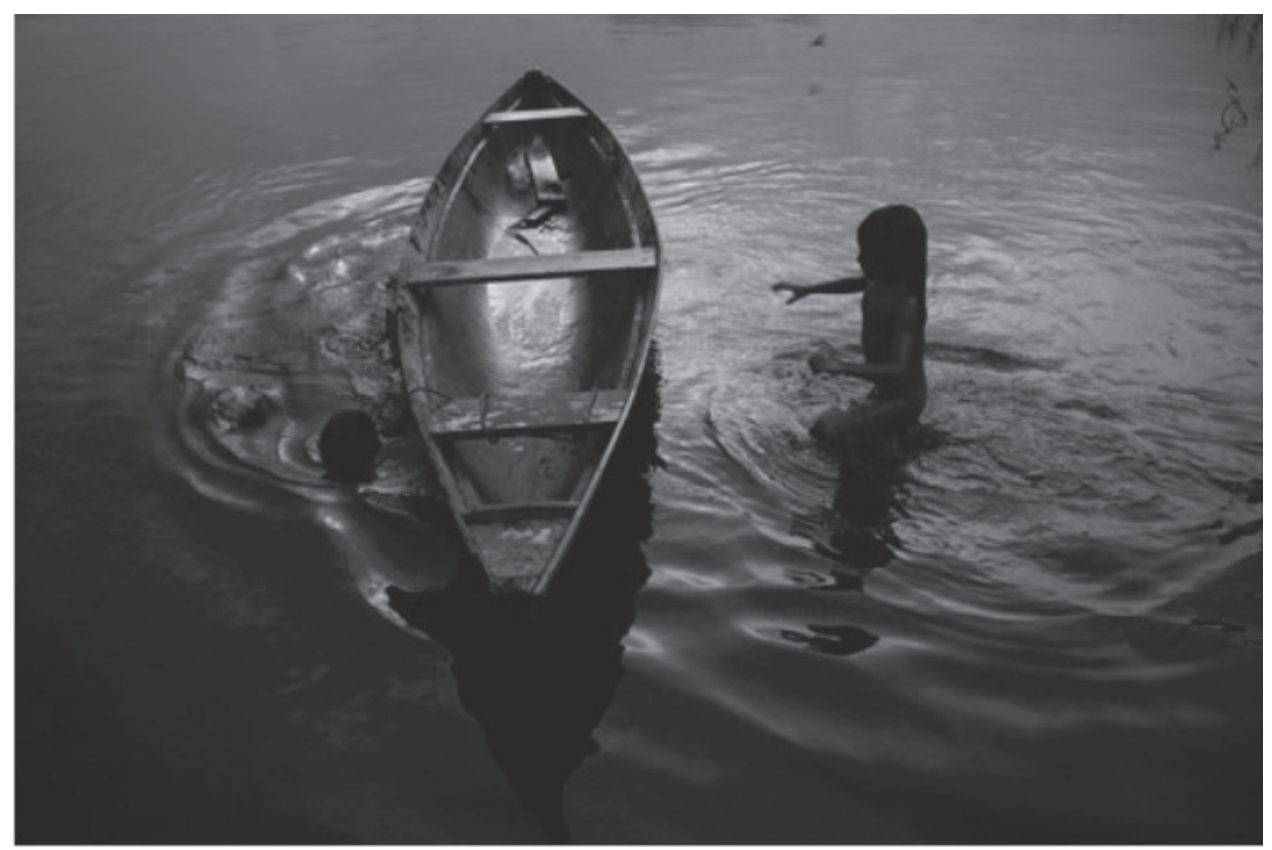

Fotografia 2. Araquém Alcântara.

A silhueta de duas crianças brincando em um rio, em torno de uma canoa, é o que se vê na fotografia 2 , que se vale dos efeitos da contraluz como elemento desencadeador de boa parte do seu sentido. A supressão da expressão facial das crianças, bem como dos detalhes da cena, na qual prevalece quase que uniformemente o tom azulado, favorece a sutileza e o mistério.

Do ponto de vista icônico, esses aspectos podem sugerir a abertura para a construção de um discurso que poderia partir da realidade dos próprios indígenas fotografados e que, por sua vez, se distanciaria tanto das adjetivações preconceituosas e dicotômicas que marcaram os discursos dos colonizadores quanto às imagens dos conflitos e disputas pela terra que ganharam repercussão nos jornais da grande imprensa brasileira no período das comemorações dos 500 anos.

Para longe dos estereótipos instituídos ao longo de anos, o mistério que marca a plasticidade dessa imagem aliado às crianças indígenas que brincam tranquilamente, revelam uma integração com o mundo do qual fazem parte, sugerindo praticamente uma fusão. Nesse sentido, ao valorizar o icônico na fotografia 2, Alcântara deixa aberta a possibilidade para a construção de um discurso que se origina dos próprios referentes fotográficos, como sugestão, não como verdade absoluta e incontestável. 


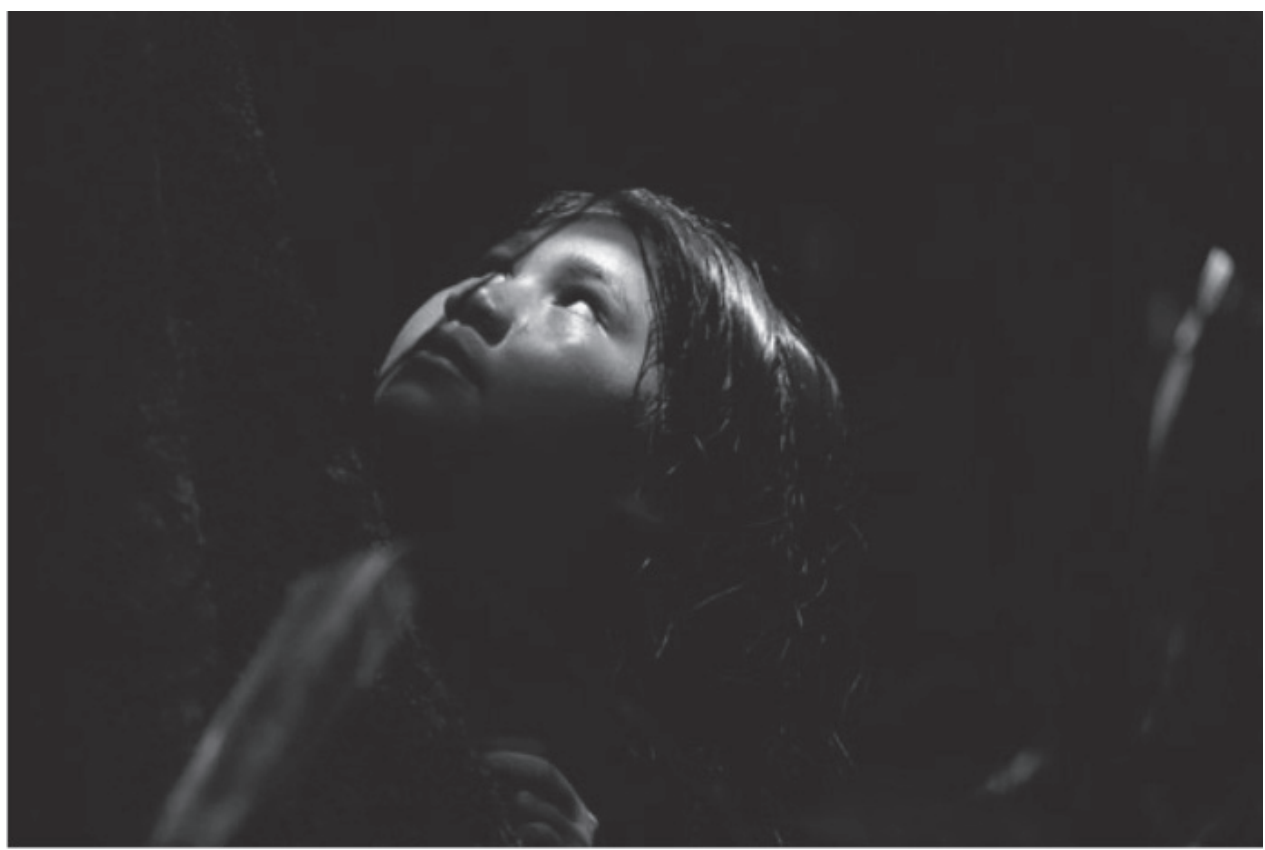

Fotografia 3. Araquém Alcântara.

Também são os aspectos icônicos que diferenciam e reforçam a possibilidade de abertura interpretativa para a fotografia 3. Dividida em uma zona iluminada e outra escura, essa imagem também evoca a instabilidade e faz emergir um jogo de mostra-e-esconde, deixando entrever as complexidades inerentes às identidades indígenas. Neste caso, a zona iluminada é constituída por parte do rosto da criança de Pari-Cachoeira. É esse pedaço do rosto, que inclui o olhar, voltado para cima, que permite a sua inscrição étnica. Ao construir essa foto a partir de um jogo de sombras, Alcântara permite a abertura interpretativa capaz de escapar de generalizações de traços que, ao longo da História, vem criando e reforçando uma série de estereótipos. 


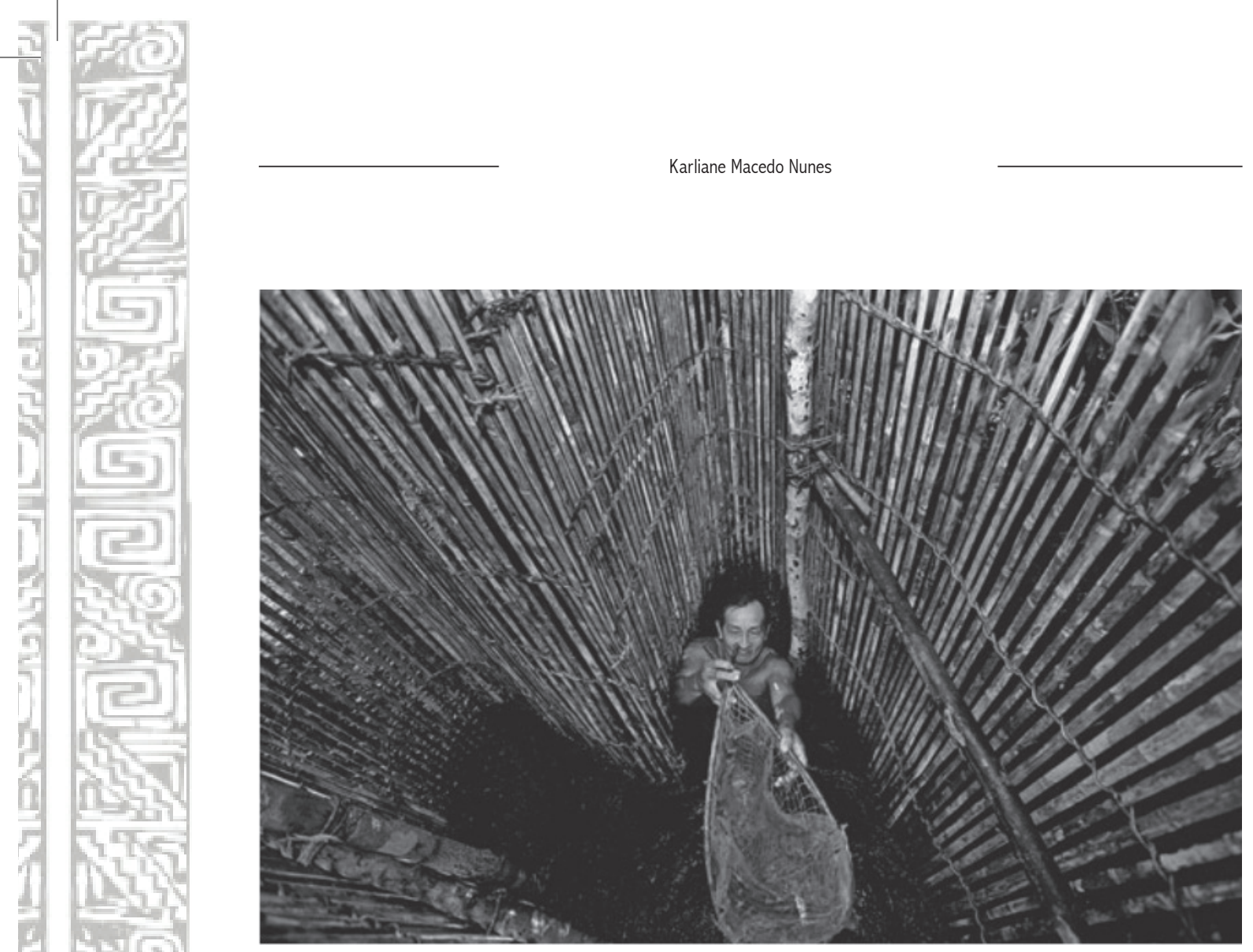


A fotografia 4, clicada de cima para baixo (um contre-plongée), mostra um homem dentro d'água, segurando uma espécie de rede, em atividade de pesca. À volta dele, um cercado de madeira, revela um pouco da sua técnica de pesca. Se tomarmos emprestado a terminologia peirceana, é possível afirmar que se trata de uma fotografia com traços indiciais: o foco bem-definido e a luz uniformemente distribuída ao longo da imagem reforçam essa ideia e fazem com que o espectador tenha acesso à imagem tal como se ele estivesse presente no momento do clique. Sobre o método de trabalho do homem da floresta, Elane Lima afirma:

O sujeito da floresta elabora o seu conhecimento no trato direto com o seu objeto. Sendo assim, para conhecer a autopoiese dos peixes, por exemplo, observa os seus movimentos, os seus gostos. Pesca-os inicialmente de forma aleatória; em seguida, estuda-os de forma detalhada para melhor conhecê-los de forma saudável e não predatória, visando respeitar os seus períodos reprodutores e pescá-los sem risco para a espécie (LIMA, 2008).

O trecho da autora sugere uma sincronia perfeita entre cultura e natureza, uma espécie de cenário no qual os protagonistas, nesse caso, os "povos da floresta" amazônica, possuem e utilizam de forma inteligente todos os conhecimentos necessários para uma vida harmoniosa e plena. O trabalho de Lima, inteiro dedicado aos saberes desses povos, considera que o pensamento dos indígenas da citada região se constitui em um sistema bem-articulado e independente da ciência.

A fotografia 4 permite que esse discurso seja acionado, mas também deixa a possibilidade para interpretações mais grosseiras, como aquelas feitas pelos primeiros viajantes no Brasil, ainda no século XVI: a de uma relação primitiva e bárbara com a natureza porque diferente da suposta "civilização" Ocidental. Nesse momento, cabe destacar Hall quando afirma que: Reduzir as culturas dos negros e indios à natureza consiste em naturalizar a "diferença", consiste em uma estratégia representacional destinada a fixar a 'diferença' e assim garanti-la para sempre (HALL, 1997, p. 75).

Já a fotografia 5 mostra, em primeiro plano, um índio curipaco, que olha para a câmera fotográfica. Em segundo plano, aparece outro índio pertencente 
à mesma comunidade, mais jovem que o primeiro. $\mathrm{O}$ espaço não é mais o da natureza. Dessa vez, os índios são fotografados dentro de um salão de concreto com paredes brancas e teto de palha. Mas do ângulo em que a imagem foi feita, não é possível saber de que espaço social se trata de fato.

O interessante nessa fotografia é notar a convivência de marcas identitárias aparentemente divergentes, que podem ser percebidas por meio dos trajes dos protagonistas das cenas: o índio mais velho, destacado na imagem, usa terno e gravata bem-alinhados, e, ao mesmo tempo, um chapéu de palha. Mobilizando mais uma vez o discurso de Lima (2008), podemos afirmar que esses povos compartilham, ao mesmo tempo, de duas esferas: uma do pensamento empírico-técnico-racional e outra do pensamento simbólicomitológico-mágico. Para argumentar, a autora cita Lévi-Strauss na sua discussão em torno da ética para a condição humana:

Garantir a unidade do humano de todas as épocas e de todos os tempos supõe apostar nessa possibilidade histórica, mesmo diante das condições adversas da modernidade. Trata-se de repensar um universalismo mediante o qual nenhum povo, nenhuma etnia, nenhuma cultura sejam tratados como objetos, mas como unidades dialógicas entre o mesmo e o outro, o próprio e o alheio. Se essa reconciliação algum dia vier a ser efetivada e, com ela, todas as dicotomias implodidas, seria possível supor que a cultura se redefina a partir da dialogia instaurativa entre natureza e cultura (LÉVI-STRAUSS apud LIMA, 2008).

As fotografias 4 e 5 se destacam por suas qualidades indiciais, ou seja, por mostrarem de maneira mais direta imagens cujas marcas prioritárias são a sua conexão física com o referente. Mas trata-se de fotografias com abordagens diferenciadas: enquanto a 4 dá ênfase à relação do homem indígena com a natureza, que a depender do discurso acionado, como foi visto, pode ser interpretado de maneiras também diferenciadas (relação de sabedoria e pertencimento ao mundo, para Lima, e relação primitiva e bárbara como nos discursos colonialistas que tiveram início no século XVI); a fotografia 5 , por sua vez, evoca o entrelaçamento cultural e a convivência de aspectos aparentemente contraditórios. 


\section{Considerações finais}

Tanto as primeiras imagens observadas (2 e 3), mais marcadas por suas qualidades plásticas, quanto as últimas (4 e 5), que impõem a mobilização de discursos sociais e históricos de forma mais contundente, confirmam a multiplicidade das identidades indígenas, que, longe de serem homogêneas, também não devem ser generalizadas. Trata-se, ao contrário, de construções singulares, e devem ser percebidas sempre em relação a esse algo que a singulariza.

Se as imagens mais icônicas abrem para as possibilidades interpretativas, permitindo inclusive a assunção de discursos mais próximos dos próprios referentes fotográficos, não devemos esquecer que o índice sempre carrega algo de icônico.

É esse diálogo entre as dimensões icônicas e indiciais que permite também a percepção de singularidades culturais, como sugeriu Albuquerque (2007), ao invés de identidades fixas, muitas vezes vinculadas a tradicionalismos e à repetição preconceituosa de estereótipos instituídos com estatuto de "certezas", nas quais os locais de fala legitimados reservam aos "outros", aos "diferentes", significados estáveis e inquestionáveis.

Nas imagens fotográficas de Alcântara, é o enlace entre o icônico e o indicial que amplia as possibilidades discursivas e legitima uma nova cultura, ou melhor, novas culturas indígenas. A esse respeito, Souza sugere: [...] o embrião de uma nova cultura, mestiça, subvertendo as noções de unidade e pureza e que se torna apta a desencadear o processo de descolonização. Temos então outra interpretação cultural que se encaixa no dinamismo ternário da semiose (SOUZA, 2006, p. 189).

Processos de construção de identidades são conflitantes e ambíguos. Representações relativas aos povos indígenas continuam sendo construídas na contemporaneidade. Nesse sentido, as imagens de Alcântara possuem um papel significativo, uma vez que podem rearticular e/ou transgredir os discursos veiculados ao longo dos tempos.

Este trabalho buscou realizar uma breve e incipiente demonstração dos aspectos imagéticos envolvidos no processo de construção de Araquém Alcântara, não tendo como objetivo, ainda, julgar os seus efeitos, apenas apontar as suas possibilidades. 


\section{Notas}

1. A dissertação de Manoela Freire, intitulada Significações históricas do "indio": leituras da mídia impressa e da literatura, de 2005, realiza um estudo minucioso dessas ações a partir de uma análise acerca da cobertura midiática realizada por jornais de grande circulação como $A$ Tarde e Folha de São Paulo, no período das comemorações.

2. Grosso modo, pode-se afirmar que Peirce define signo como um primeiro que está em relação com um segundo, e que é capaz de determinar um terceiro. Assim, o signo é entendido enquanto uma função, em uma perspectiva completamente diferente da teoria estruturalista da linguagem.

3. Publicado pela Editora Terra Brasil. Simultaneamente, o fotógrafo lançou mais dois livros: Bichos do Brasil e Mata Atlântica.

\section{Referências}

ALBUQUERQUE, Durval. Fragmentos do discurso cultural: por uma análise crítica do discurso sobre a cultura no Brasil. In: NUSSBAUMER, Gisele (Org.). Teorias e politicas da cultura. Salvador: Edufba, 2007.

ALCÂNTARA, Araquém; VARELLA, Dráuzio. Cabeça do Cachorro. São Paulo: Terra Brasil, 2008.

BARBOSA, Andréa; CUNHA, Edgar Teodoro. Antropologia da imagem. Rio de Janeiro: Jorge Zahar Editora, 2006.

CAMPELO, Cleide Riva. Cal(e)idoscorpos: um estudo semiótico do corpo e seus códigos. São Paulo: AnnaBlume, 1997.

FLUSSER, Vilém. Filosofia da caixa preta: ensaios para uma futura filosofia da fotografia. Tradução do autor. Rio de Janeiro: Relume Dumará, 2002.

FREIRE, Manoela. Significações históricas do "indio": leituras da mídia impressa e da literatura. Dissertação - (Mestrado) - Programa de Pós-graduação em Letras e Linguística, UFBA. Salvador, 2005.

HALL, Stuart. The spectacle of "other". In: Representation. Cultural Representations and Signifying Practices. London: Thousand Oaks; New Delhi: Sage/Open University, 1997. 
LIMA, Elane. Diálogos com a natureza, saberes dos povos da floresta amazônica. In: ENCONTRO DE ESTUDOS MULTIDISCIPLINARES EM CULTURA, 4, Anais IV ENECULT, Salvador: Ritos Produções, 2008.

NUNES, Karliane Macedo. Reflexões para uma metodologia multidisciplinar de análise fotográfica. Revista Travessias. Ed. 03, 2008, ISSN 1982 - 5935.

PEIRCE, Charl. Semiótica. 3. ed. Tradução de José Teixeira Coelho Neto. São Paulo: Perspectiva, 1990.

SOUZA, Lícia Soares. Introdução às teorias semióticas. Petrópolis, RJ: Editora Vozes, 2006 